$\square$ 生態系保全学 $\square$ 総 説

\title{
地球温暖化防止対策と野生生物の保護について
}

安本守宏

北海道大学大学院地球環境科学研究科化学物質循環講座 $\bar{T} 060-0810$ 札幌市北区北 10 条西 5 丁目

現所属：北海道宗谷家畜保健衛生所 $=098-5738$ 北海道枝幸郡浜頓別町緑ヶ丘 8 丁目

（2003 年 7 月 15 日受領, 2004 年 8 月 25 日採択）

\section{Relationship between Wildlife Conservation and Global-Scale Environmental Problems - An Example of Global Warming Mitigation Measurements -}

\author{
Morihiro YASUMOTO \\ Laboratory of Marine and Atmospheric Geochemistry, Graduate School of Environmental Science, \\ Hokkaido University. Sapporo 060-0810, Japan \\ Current Affiliation : Hokkaido Soya Livestock Hygiene Service Center, Hamatonbetsu 098-5738, Japan
}

\begin{abstract}
This study applies the idea of global warming mitigation to the conservation of threatened wildlife. Although healthy habitats are quite indispensable for appropriate wildlife management, habitat destruction results in undermining the richness of species wildlife, releasing carbon dioxide into the atmosphere. Keeping land biomes healthy should be considered to solve the problems. In relation to the serious deterioration of wildlife habitats, healthy land biomes (biodiversity hotspots) serve as a large reservoir of carbon in terrestrial ecosystems. Simultaneously, the healthy land biomes have a large capacity to uptake atmospheric carbon dioxide. Reconstructing natural and healthy land biomes will enlarge the capacity of carbon uptake in terrestrial ecosystems and prevent further global warming. In line with this scenario, we recommend the strategy for reconstructing natural environments, especially, the natural forest reconstruction method and the naturally diverse river construction method, as a first step to recover natural and healthy terrestrial ecosystems.
\end{abstract}

Key words : carbon dioxide, global warming, habitats, reconstruction of natural environments, wildlife conservation.

Jpn. J. Zoo. Wildl. Med. 10(2) : 65-78, 2005

\section{はじめに}

16 世紀に産業革命が始まってから今現在に至るまで, 地 球規模の自然破壊が人間活動によって加速度的に進行しつつ あり，早急なその解決が望まれている [1-4]。また，地球規 模の様々な環境問題が深刻化しているが，それぞれの問題に 対して個別に対応していくよりも統合的に捉えた対策が望ま しく，地球温暖化問題についても同様な指摘がなされている [4]。陸域生態系は炭素の吸収源として大きな役割を担って いるので,この吸収能力は, 気候変動に関する政府間パネル (Intergovernmental Panel on $\underline{\text { Climate }}$ Change : 以下, IPCC) において地球温暖化を防止するために有効であるとされている [4]。IPCCによると，1990 年代には，炭素換算で年間平均 6.3gigatons carbon（Gt C）の二酸化炭素が人間活動により大 気へ放出された。そのうち約半分にあたる $3.2 \mathrm{Gt} \mathrm{C}$ は大気へ残

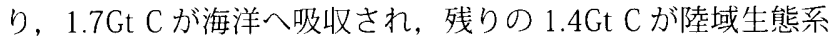

へ吸収された [5]。すなわち, 陸域生態系の維持確保は, 地 球温暖化防止対策において炭素の吸収源として有効となる。そ れは, 同時に野生生物の生息地の維持確保としても有効となる $[4,6]$ 。

そこで本稿では, 野生生物の保護管理には健全な生息地の維 持確保と復元が必要不可欠であるという立場に基づき $[3,6]$, 考察を進めていく。最初に地球温暖化の現状と防止対策につい て記し, 次に現在の野生生物種の減少扔よび絶滅はいかに深刻 であるかを記す。そして最後に炭素循環からみた地球温暖化防 止対策をどのようにして野生生物の生息地の維持確保と復元に 活用できるのかを考察する。

\section{地球温暖化の現状と防止対策}

\section{地球温暖化問題の浮上とその科学的根拠}

1956 年，地球についての知識を深めるため, 地球観測年 (International Geophysical Year：以下, IGY) を設け，世界各 
地において気象を含む様々な観測が行われ，1958 年からハ ワイのマウナロアにおいて大気中 $\mathrm{CO}_{2}$ 濃度の連続測定が開始 された $[7]$ 。測定開始から約 10 年後, $\mathrm{CO}_{2}$ 濃度の確実な上昇 が確認された。また，八ワイのマウナロアだけではなく，ア ラスカや南極においても $\mathrm{CO}_{2}$ 濃度の確実な上昇が確認された [8-10]。それより以後今日に至るまで，マウナロアでは連続 測定が続けられており， $\mathrm{CO}_{2}$ 濃度は微細な変動を繰り返しなが ら一貫して指数関数的な上昇を続けている(図 1)。それに加え， メタンやハロカーボン類などの温室効果気体（Green House Gases：以下，GHGs）の大気中濃度も上昇を続けていること が続々と明らかになった。現在では世界中に観測点が設けら れ，アメリカ海洋大気省（National Oceanic and Atmospheric Administration：以下，NOAA）をはじめとして大気中 GHGs 濃度の連続測定が行われており，将来の地表気温上昇は確実視 されている。国内においても, 岩手県の綾里や北海道の落石, 茨城県の筑波などに連続測定観測点を設け，同様な結果を得て いる $[11,12]$ 。NOAA は, 1990 年代末に「地球温暖化は確
実に進行している」と公式発表した。

このような大気中 GHGs 濃度の急激な上昇が全世界において 確認された現在，地球温暖化問題は大きな研究対象となった。 実験気候変動学といわれる分野においては，大型計算機を用い た将来予測や古環境復元を行って着実に成果をあげており，こ の成果は IPCC においても高い評価を受けているので紹介する [5]。

\section{地球温暖化の進行によって懸念されること}

ここでは, 2001 年に作成された IPCC 第三次報告書が最も 信頼性がおけると判断し, 主にこの報告書の予測值を用いる $[5,13]$ 。なお, 以下に使用する語句として，「予測される」は 多数のシナリオが存在するので予測值の幅が大きく,「可能性 が高い」は将来の実現性が 66 ～90\%,「可能性がかなり高い」 は実現性が 90 〜99\%であることを示す。

(1) 海面の上昇について

地球の平均海面水位は, 潮汐計のデータから, 20 世紀に $0.1 \sim 0.2 \mathrm{~m}$ 上昇した。この上昇の大部分は海水の熱膨張と水

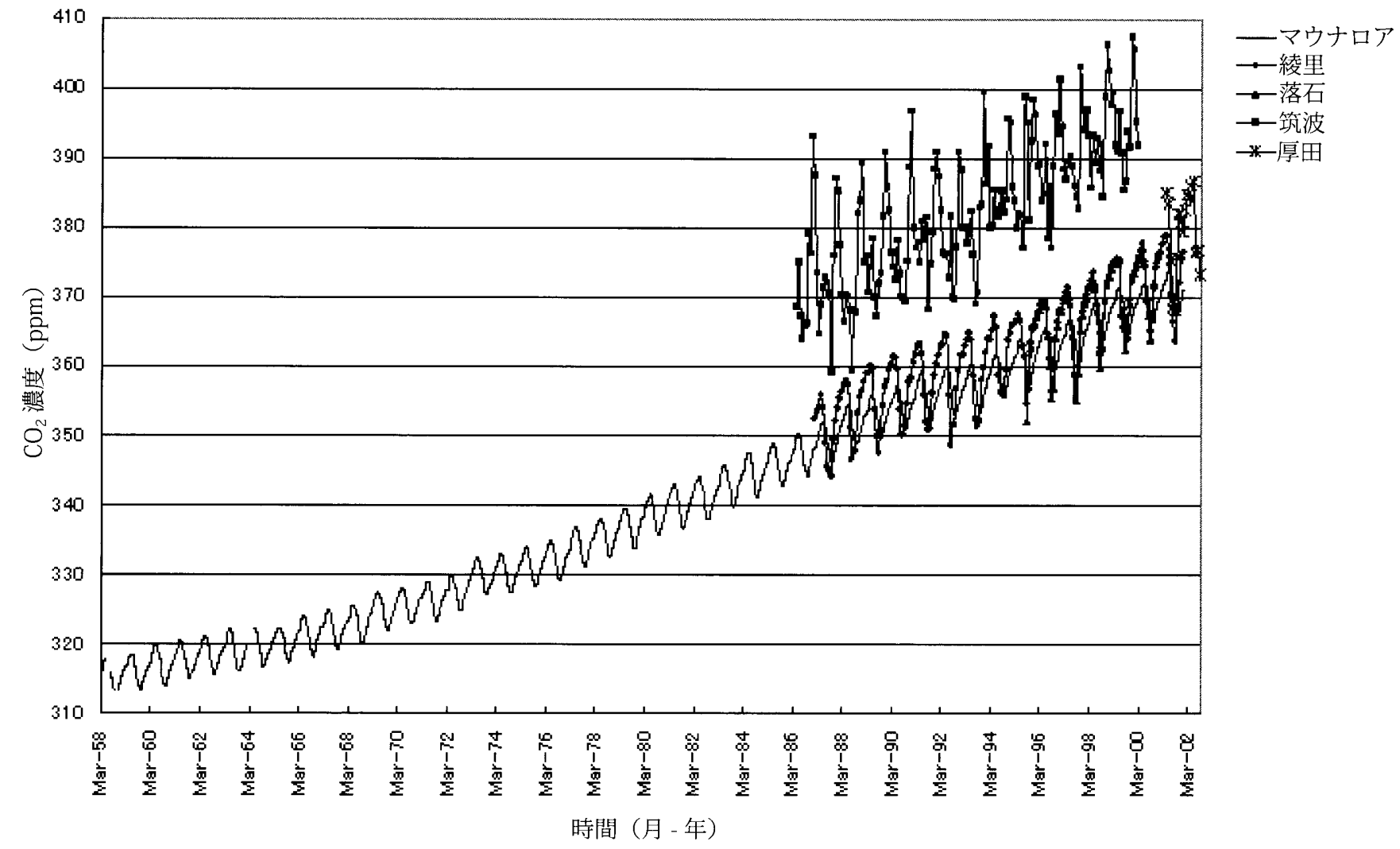

図 1 大気中 $\mathrm{CO}_{2}$ 濃度の時間変動

$\mathrm{CO}_{2}$ 濃度を $\mathrm{ppm}$ 単位で縦軸に, 測定が開始された 1958 年 3 月からの時間を横軸に示した（データ提供：温室効果ガス 世界資料センター。ただし，厚田は，著者による測定值である)。マウナロア：19.3 N, $155.4 \mathrm{~W}, 3397 \mathrm{~m} \mathrm{MSL}$. 綾里 : 39.2 $\mathrm{N}, 141.5 \mathrm{E}, 230 \mathrm{~m}$ MSL. 落石：43.9 N, 145.3 E, 45 m MSL. 筑波：36.3 N, $140.8 \mathrm{E}, 26 \mathrm{~m} \mathrm{MSL}$. 厚田：43.2 N, $141.3 \mathrm{E}, 27$ m MSL. 


\section{野生生物の保護に携る地球温暖化防止対策}

床の融解によるものである。今後は 2100 年までに最大 $0.88 \mathrm{~m}$ 上昇すると予測される。なお，海面の上昇は様々な気候变動に 伴って起こる結果であり，そこへ至る過程としての劇的な気候 変動がもたらす災害が最も懸念されている。

（2）劇的な気候変動

地球の平均地上気温は, 20 世紀に約 $0.6^{\circ} \mathrm{C}$ 上昇した。 20 世 紀における気温の上昇は, 過去千年のどの世紀よりも大きかっ た可能性が高い。近年得たより信頼性の高い証拠によると，過 去 50 年内に観測された温暖化のほとんどは人間活動によるも のである。今後, 人為起源による温暖化は 10 年間あたり 0.1 〜 $0.2^{\circ} \mathrm{C}$ になる可能性が高い。2100 年までには, 地球の平均 地上気温は $1.4 \sim 5.8^{\circ} \mathrm{C}$ 上昇すると予測される。この予測され た気温上昇率は，20世紀に観測された值よりもはるかに大き く, 古気候のデータから, 少なくとも過去 1 万年の間に観測 されたことのないほどの大きさである可能性がかなり高い。ま た，ほとんどすべての陸域で最高気温および最低気温が上昇す る可能性がかなり高い。つまり, 暑い日が増加し, 寒い日や霜 が降りる日が減少する。なお，これらの予測值は，予測期間に おける長期傾向を示しており，微細な変動を意味するものでは ない。

\section{（3）気候変動がもたらす食料危機}

夏の大陸で乾燥しやすくなり，干ばつの危険性が増加する。 中緯度の大陸内部の大部分でその可能性が高い。これに伴って, 食料の生産に大きな被害が扔こると予測される。しかしながら, 地域ごとの詳細な予測は現時点では難しい。

（4）熱带性感染症の増加

温暖化の進行に伴う気候変動は熱帯性感染症の蔓延地域を 拡大させるという考えに対し，むしろ他の要因，感染生物の移 動経路や他の生物との接触による影響の方が大きいという考え があり, 疫学的に正確な予測は困難である $[14,15]$ 。しかし, 温暖化は全球規模で進行しているので，ほぼすべての感染症に 対して少なからず影響を及ぼすと考えられる。大規模森林伐採 に伴う新興感染症の大発生や再興感染症の蔓延が懸念されてい るが，IPCCによると，ほとんどの地域で熱指数が大きくなる 可能性がかなり高いとされており，日和見感染症の増加も懸念 される。

いずれにせよ，活発な人間活動は感染症の蔓延を促すという 考えは一致した見解であり，予防医学の立場から，自然宿主や 感染生物の生態のみではなく，各種病原体の生態を探る必要性 が高まっている [14-19]。

\section{急激な地球温暖化進行の可能性}

IPCC 第三次報告書は，各国の研究成果をまとめて作成され ており，最も信頼がおける。しかし，十分な考慮がなされてい ないとの指摘がある。一例を挙げると, 海底岩盤中に大量に存
在するメタンハイドレートは, 海水温の上昇によって不安定に なり, それが大気へ一時に放出されると気温上昇に正のフィー ドバック効果が働き, 温暖化は IPCC の予測值を上まわって加 速度的に進行するという指摘がある $[20,21]$ 。その反面, メ タンハイドレートを石油石炭の代替エネルギーとして用いる動 きが盛んであるので，意見は 2 つに分かれている [21]。メタ ンハイドレートを掘削する際には海水とメタンハイドレート層 が接触する機会を生じるので, 底生生物へ悪影響を及ぼし，メ タンの放出を促す危険性が高く, 確実なアセスメントが求めら れる $[21] 。$

\section{地球規模の炭素循環}

ここでは，大気中 $\mathrm{GHGs}$ として名高い $\mathrm{CO}_{2}$ の循環をみたい。 $\mathrm{CO}_{2}$ の循環を表す場合, 炭素換算量を $\mathrm{Gt} \mathrm{C}$ で表記するので, ここでもそれに従う。人間活動を考慮しなければ, 大気圏には $730 G t$ C, 海洋圈には 38,000Gt C, 陸上生物圈には 2,000Gt C の炭素が存在する（表 1)。次に，これらの眝蔵庫間の $\mathrm{CO}_{2}$ の 収支をみてみる（表2）。以下に用いる值は，すべて全球収支 を年間平均で示し, 標準偏差は 1 ○である。人間活動による 大気への炭素放出量は，1980 年代には $5.4 \pm 0.3 G t$ C, 1990 年代には $6.3 \pm 0.4 \mathrm{GtC}$ であり，そのうち約半分が大気へ残り， 大気中 $\mathrm{CO}_{2}$ 濃度を増加させている（図 1)。なお, 陸の炭素吸収 能力は, 1980 年代には $0.2 \pm 0.7 \mathrm{Gt} \mathrm{C}$ であり, 1990 年代に は $1.4 \pm 0.7 \mathrm{Gt} \mathrm{C}$ である。この増加量については, 大気中 $\mathrm{CO}_{2}$ 濃度の増加によって陸上植物の成長が促進された結果であると されている [5]。また, 海洋の炭素吸収量は, 1980 年代には $1.9 \pm 0.6 \mathrm{Gt}$ C であり，1990 年代には $1.7 \pm 0.5 \mathrm{Gt} \mathrm{C}$ である。 海洋の炭素吸収能力は，年々減少しつつある [22]。

現在考えられている地球温暖化防止対策とその成果，問題点 地球温暖化防止対策は始まったばかりであり, 現在, 増加率

表 1 各貯蔵庫における炭素の存在量 ${ }^{1)}$

\begin{tabular}{cc}
\hline 眝蔵庫 & 炭素の存在量 $(\mathrm{Gt} \mathrm{C})$ \\
\hline 大 気 & 730 \\
海 洋 & 38000 \\
陸 & 2000 \\
\hline 1) 炭素換算量を gigatons carbon (Gt C) で示し \\
た。IPCC Working Group I (2001)より引用。
\end{tabular}

表 2 全球的な炭素の収支量

\begin{tabular}{ccc}
\hline & 1980 年代 & 1990 年代 \\
\hline 人間活動 & $+5.4 \pm 0.3$ & $+6.3 \pm 0.4$ \\
大 気 & $+3.3 \pm 0.1$ & $+3.2 \pm 0.1$ \\
海 洋 & $-1.9 \pm 0.6$ & $-1.7 \pm 0.5$ \\
陸 & $-0.2 \pm 0.7$ & $-1.4 \pm 0.7$ \\
\hline 1) 年平均值 を GtC で示した。+は大気への放出, 一は大気からの \\
吸収を意味する。 IPCC Working Group I (2001) より引用。
\end{tabular}


の減少傾向が確認された大気中 GHGs は，モントリオール議定 書に基づくハロカーボン類のみである [5]。全球規模の炭素 循環から考えると, 地球温暖化防止対策は, 結局のところ炭素 の放出量を削減する，もしくは，すでに大気へ放出された炭素 を陸か海へ回収するしか手段はない。ここでは現時点で考えら れている地球温暖化防止対策について記す。

(1) 炭素放出量の削減

1997 年 12 月，京都において採択された炭素放出削減量の 目標值は, 先進国全体で, 1990 年の基準值に対して, 第一拘 束期間である 2008 年から 2012 年までに少なくとも $5 \%$ の削 減であった [23]。しかしながら，この実行は炭素放出権の取 引問題などから動向が激しく [24], 世界のエネルギー消費に 伴う炭素の放出量は, 依然として増加傾向にある [5]。

（2）海洋への投棄

炭素が大気中へ放出される前に，もしくは，すでに大気中へ 放出された炭素を海洋へ直接投棄する様々な試みがある。一例 を挙げると, 工業生産によって放出された $\mathrm{CO}_{2}$ を海洋へバブ リングし, 海水へ溶存させるという方法がある [25]。しかし ながら, 確実なアセスメントを行ってから実用へと至るまで今 しばらく時間を要する $[26]$ 。

（3）陸の有効活用

著者は, 現時点ではこの方法が最も安全かつ効果的な地球温 暖化防止対策になると考えている。陸域生態系へ炭素を貯蔵さ せていく戦略であるが, 再植林や新規植林を行って陸の緑化を 推進させつつ, 河川を通じて海洋の一次生産を促進する方法で ある [27-34]。その具体的な方法について次に述べる。

\section{自然環境復元の技術}

自然環境を復元する技術は，日本ではその方法論の基盤が 1990 年代初頭にすでに提示されており, 各種研究教育機関や NPO 団体, 市民および行政関係者の地道な努力によって, 近年, その成果が実り始めた方法である [35, 36]。1990 年代後半 には, 自然環境復元の実施に伴って生じる多様な利害関係者の 参加と合意形成の上で, その実行を順応的にかつ政策的に進め る方法として「順応的管理」という公的なシステム管理の手法 が提示された [36]。基本的には, 自然環境復元の技術は人の 手によって自然の回復能力を促す技術である。ここでは自然環 境復元の技術について概説し, 得られた成果, 問題点および課 題について記す。

\section{陸の緑化技術について}

陸を緑化させるための方法には様々な技術があるが, ここで は極めて天然林に近い植生を回復させる技術を紹介する。火山 噴火や洪水, 森林火災などによって裸地が出現すると, 天然更 新によって植生の回復が進む。天然更新は, ヤナギ類やハンノ
キ類, カンバ類などの先駆性樹種がいち早く成長し, この保護 下で針葉樹類やミズナラ, シナノキなどの持続性樹種がゆっく りと成長して巨木林へと至る。その過程で, 昆虫類, 鳥類およ び小動物が定着してゆき，大型動物が定着可能な土地となる。 しかしながら，巨木林へと至るまでには，通常数十年から数百 年の歳月を要する。このような天然更新を，人工的に高める技 術が存在する $[27,28]$ 。この方法を, 以下では自然林再生法 と記す。自然林再生法は, 地域の固有樹種を貧栄養下で育成し た苗や種子を定めた面積内に数種類まとめて植える方法を用い ている。したがって，その地域の気候に適した樹種が自然選択 を受けながら, 不秩序に成長していく。この際, 植樹域にマル チングを施し，なおかつ貧栄养下で育成した苗を植えるので, 通常の天然更新よりも速い速度で自然林が定着する。植える樹 種は地域の固有種なので，地域に適した野生生物が生息しやす い再生自然林を形成していく。写真 1 は, 自然林再生法の施 工地の現在の様子である。A 地では施工後約 11 年, B 地では 施工後約 25 年が経過している。いずれの土地も，かつては原 野であった。表 3 にB 地内の鳥類調査結果を示した。調査は, $1991 \sim 1993$ 年（施工後 $13 \sim 15$ 年）にかけて行われ, 25 科 58 種の生息が確認された。冬の強い季節風に耐えうる防風 林として施工された面積わずか 65 ha という閉鎖緑地内として は，鳥類の生息種の割合は高いといえる [28]。さらに, 15 科 27 種の繁殖が確認されている。

\section{多自然型河川工法について}

この工法は, 1980 年代末から 1990 年代前半にかけて日本 へ導入され，現在普及しつつある方法である。多自然型河川工 法は野生生物が生息可能で, なおかつ治水機能を備えた河川を 造る方法であるが，施工法の画一的な記述は，河川の地域性や 個別性に依存する場合が多いので難しい。しかし，施工法には ある程度の原則的な側面があるので，これに沿って記す。施工 にあたって重要な点は, 自然林再生法と同様に, その地域に適 した河川を再生するということである。それにはまず，古地図 等の歴史的な資料を参考にして從来の河川改修がなされる以前 の天然河川の特徵を探り, 河川に適度な蛇行や落差, 瀬, 淵を 持たせつつ河床を拡大し, 可能な限りコンクリート護岸を取り 払い, 護岸には火成岩や堆積岩, 変成岩などの自然石を用いて 土壌と河川水の接触面積を拡大させ，護岸林には地域に固有な 先駆性樹種や鳥慨木を採用して多様な生物が生息しやすい初期 デザインを作成し，これに基づいて施工する。そのため，自然 林再生法と同様に地域に適した溪流魚や水鳥などの野生生物が 生息しやすい河川生態系を形成していく。施工完了後も追跡調 査を行い, 新たな問題点を発見したらそのつど最適化を図り, さらに改良を加えていく。つまりは, 順応的管理を適切に機能 させることが求められる。 

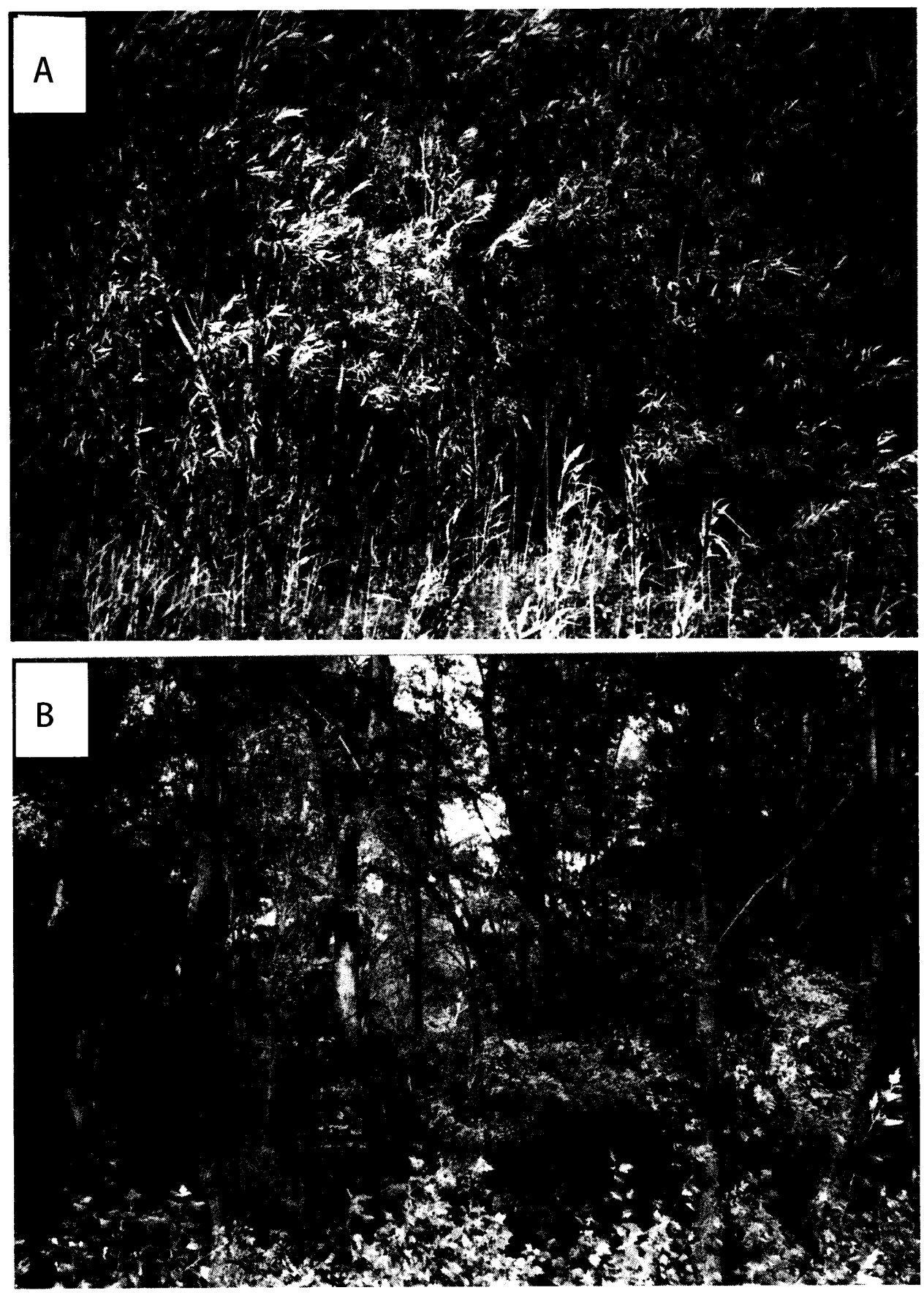

写真 1 台狩市に捕ける日然林再牛法の施工地

A 地は施上後約 11 年が経過して抢り，先駆性樹種であるヤナギとともに：ミズナラやエゾ ヤマザクラ、アキグミなどの持続性樹種の成辰が確認されている。また, 野鳥や小動物, 昆出

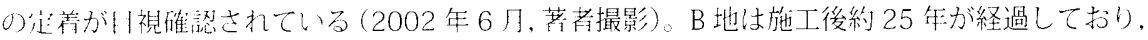

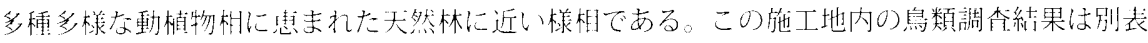
へ小した（2003年９１，著学撮影）。 
表 3 自然林再生法施工地内における鳥類調查結果 )。25 科 58 種の生息が確認されている。

\begin{tabular}{|c|c|c|c|c|c|}
\hline 科 名 & 和 名 & 繁殖 2) & 科 名 & 和 名 & 繁殖 2) \\
\hline \multirow[t]{3}{*}{ ワシタカ科 } & ト ビ & + & & キクイタダキ & \\
\hline & ノスリ & & & センダイムシクイ & \\
\hline & オオタカ & & & エゾムシクイ & \\
\hline ハヤブサ科 & チゴハヤブサ & & (ヒタキ亜科) & ノビタキ & + \\
\hline キジ科 & コウライキジ & & & ルリビタキ & \\
\hline \multirow[t]{2}{*}{ シギ科 } & イソシギ & & & キビタキ & \\
\hline & オオジシギ & & & オオルリ & \\
\hline 八ト科 & キジバト & + & エナガ科 & シマエナガ & \\
\hline ホトトギス科 & カッコウ & + & シジュウカラ科 & シジュウカラ & + \\
\hline アマツバメ科 & アマツバメ & & & ハシブトガラ & + \\
\hline \multirow[t]{5}{*}{ キツツキ科 } & アリスイ & + & & ヒガラ & \\
\hline & アカゲラ & + & ゴジュウカラ科 & ゴジュウカラ & \\
\hline & ヤマゲラ & & キバシリ科 & キバシリ & \\
\hline & コゲラ & + & メジロ科 & メジロ & \\
\hline & クマゲラ & & ホオジロ科 & ホオジロ & + \\
\hline ヒバリ科 & ヒバリ & + & & ホオアカ & + \\
\hline ツバメ科 & イワツバメ & 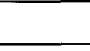 & & アオジ & + \\
\hline \multirow[t]{2}{*}{ セキレイ科 } & ハクセキレイ & + & & カシラダカ & \\
\hline & ビンズイ & & アトリ科 & カワラヒワ & + \\
\hline ヒヨドリ科 & ヒヨドリ & + & & ベニマシコ & \\
\hline \multirow[t]{2}{*}{ モズ科 } & モ ズ & + & & $\dot{y} x$ & + \\
\hline & アカモズ & + & & アトリ & \\
\hline ミソサザイ科 & ミソサザイ & + & & ウ ソ & \\
\hline \multirow[t]{4}{*}{ ヒタキ科 （ツグミ曲科） } & アカハラ & + & ハタオリドリ科 & スズメ & + \\
\hline & ノゴマ & + & ムタドリ科 & コムクドリ & + \\
\hline & ツグミ & & & ムクドリ & + \\
\hline & コルリ & & カラス科 & ハシブトガラス & \\
\hline \multirow[t]{2}{*}{ (ウグイス姍科) } & エゾセンニュウ & + & & ハシボソガラス & \\
\hline & コヨシキリ & + & & ミヤマカケス & \\
\hline
\end{tabular}

2)十は，施丁地内で繁殖が確認されている種を示す。15科 27 種の繁殖が確認されている。

先に記したと抢り，施工法の画一的な記述は難しいので，1 つの事例として北海道の恵庭市，漁川と茂漁川几多自然型河川 工法を導入した際の最適化の手順を以下に紹介する。茂漁川は 漁川支流の一級河川であり，かつてはサケの遡上もみられた。 しかし, 恵庭市は, 昭和 30 年代から急速な市街地化に伴って 河川改修が進み，河川の自然は損なわれ，サケの遡上や魚類の 個体数は減少傾向となり，度々洪水にみまわれた。そこで，従 来の河川改修を見直し，かつての自然を取り戻しつつ治水機 能を備えた河川を再生するために地域住民，学識経験者抢よび 行政関係者によるワークショップを開催し，多自然型河川工法 の導入へと至った [37]。漁川流域はカワセミやショウドウッ バメの営巣地である。カワセミは主に魚類を, ショウドウッバ メは空中の昆虫を捕えて慨とし, 水辺の砂質や粘士質へ巣穴を
掘って繁殖する。そこで，カワセミとショウドウッバメが繁殖 しやすい河川の再生を目指したデザインの最適化を行った。ま ず，1990 年から床止を改良して魚類の遡上を可能にしつつ護 岸植生を回復した結果, 漁川ではサクラマスやサケの新たな自 然再生産の増加が確認され, 餌の確保に成功した。現在, 漁川 流域のカワセミやショウドウツバメの繁殖数はやや增加傾向を 示して扔り, 追跡調査を行いつつ, さらなる改良を考慮してい る[38]。また，漁川支流の茂漁川ではハンノキ，ハルニレお よびミズナラなどの樹木, トビケラ類, カワゲラ類およびカゲ ロウ類などの水生昆虫, ヤマメ, エゾウグイ掠よびフクドジョ ウなどの魚類の再定着が確認されており，アカゲラ，八クセキ レイ, カワセミ抽よびショウドウッバメの飛来がみられるよう になった。なお，漁川と茂漁川の多自然型河川工法を成功へ導 
いている装网は，显庭市が川を中心とした環境教育に力を人れ ていること，地域住洰，学識経験者抢よび行政関係者の深い連 携が羊せられていること，ならびに施亡河川流域の自然度が高 いとこるにあると考えられる[37-41]。他の成功事例としては， バンケナイ川のコンクリート連節ブロックを外して河床基質を 㸛川させたところ、サクラマスとエゾウグイの生息密度が回復 した、サツナイ川においてショウドウツバメの集団営巣地を確 保したという派筧がある [42.43］。また，札幌市内の安春川 に毛多燃型河川工江が導人され，水鳥の飛来や昆虫の再定着 が川视確愁さ㧈て抢り，都打空間のビオトープとして機能する

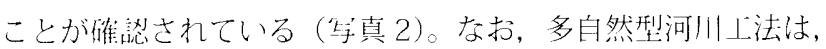

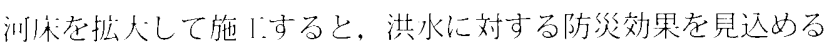
$[447$.

\section{湖沼や湿地，農地などの水辺の自然環境復元について}

湖沙，滥地抢よび農地のように，水脈の確保が容易な上地に

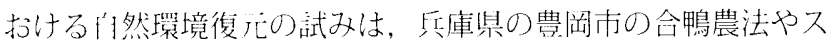
イスのチューリッヒ湖等など，成功事例が多いといえる $[44$ ， 45，。施「法0聂適化は，基本的には多自然型河川工法と问様 な下順で行う。成功事例の中から, 北海道の十勝川下流域に湿 地性:のビオトープを復元した事例について記す。十勝川中下流 域は，かつては庄人な湿原であったが，河川改修に伴って湿地 0)乾燥化が進み、単純なクサヨシ群落となった。1999 年, こ のクサヨシ教济を掘削し，十勝川水系の河川や雪解け水から 水脈を得て湿地性のビオトープを新たに造成したところ，クサ ヨシ将落には生息できなかった生物種数が増加した。表 4 は, この洋地性:のビオトープ内で新たに確認された特物種のうち, 希少種と倍急種，絶滅危惧種の一覧である。この造成地では造
成後も追跡調查を続けており, 絶滅危惧種の定着の增加が確桬 されつつある [46]。な抏，この事例を成功へと導いている娶 因は，十勝川流域の水質が良好であり，なおかつ施..测川流域 の自然度が高いところにあると考えられる[39,40]。

\section{海洋沿岸域の自然環境復元について}

干鼬などの海洋治岸域の自然環境復元は, 極めて困難である。

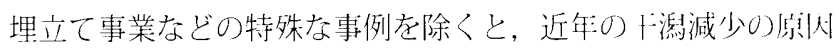
の大半は、干潟を形成する河川流域の十地利朋の变化がもたら す砂砅供給の減少，もしくは治注海流の变化による侵食の進行 にあると考えられる[33，47]。しかし，海洋沿岸域は，多様 な野生生物の生息地であり, 干潟は渡り鳥の渡来地であるので, この重要さを疑う余地はない。広島輿の八幡川河|域に造成さ れた人工干潟では, 䀣命な努力にもかかわらず, ヒドリガモ, ハマシギ，ユリカモメおよびコサギの渡来数の減少倾们が人! 干潟の造成後も続いているので, 残念ながら十分な戊果は得ら れていない[48]。しかしながら，緩和措置としての效楼はあ るといえる。

\section{人間の居住空間について}

先に紹介した自然環境復元の技術を推進していくにあたつ て, 人間の居住。空間の確保が大きな課題となる。印然壊境復元 の推進は, 特に人「過密な都市では難しい。そ执え, 人間の 居住空間は, 今後は Compact City（著者意訳:以卜，集約都师）

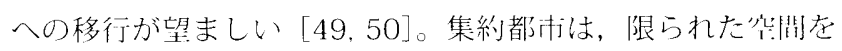
有効活用し，少ないエネルギーを效率良く用いて快適な居住: ‘等

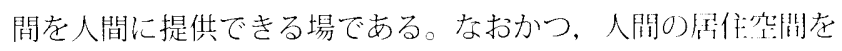
効㻭良く用いるので,野牛:牪:物が生息可能な十地を㧴人できる。

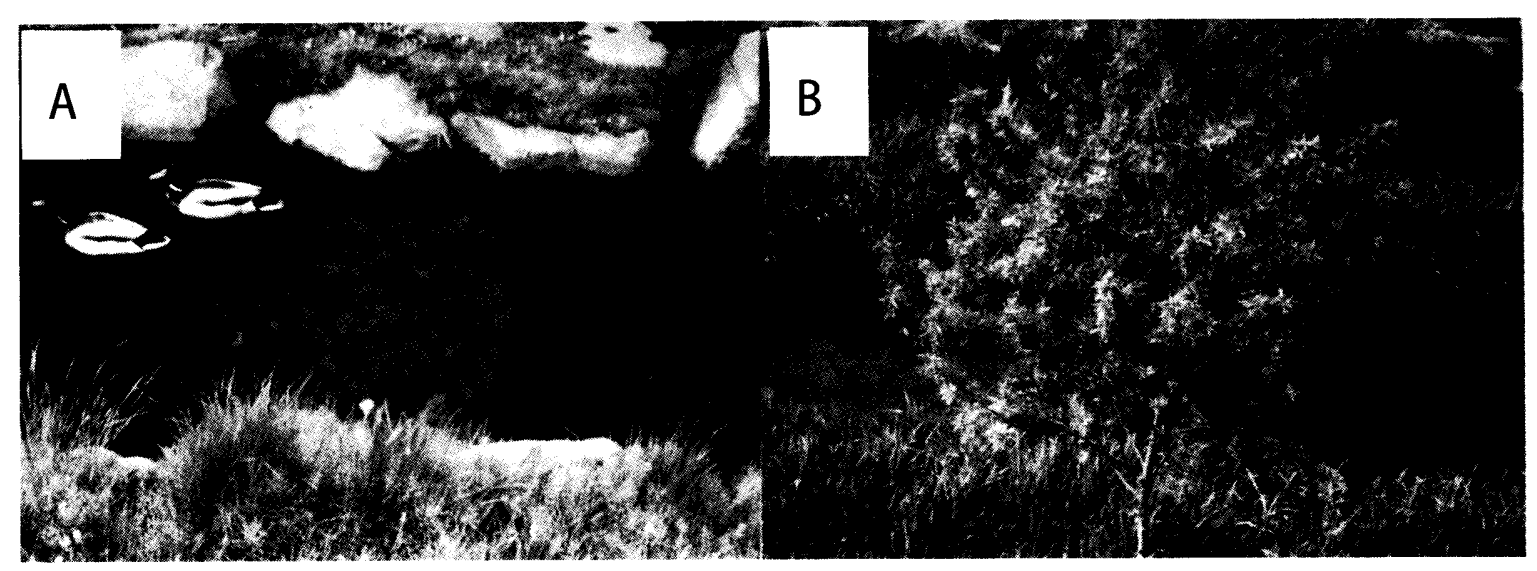

写真 2 札幌市近㬵における多自然型河川工法の施丁地

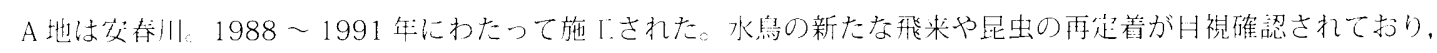

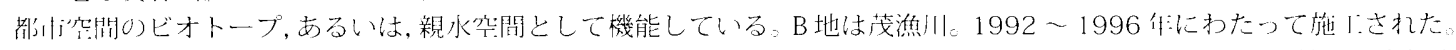
水鳥の我来や滛流重，水生尼虫の再定着が確認されている。両施丁地ともに謢岗には自然石を用い，護岸林には鳥䬣木

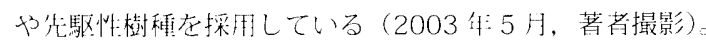


安本 守宏

表 4 造成した湿地性のビオトープ内で確認された絶滅危惧生物 11

\begin{tabular}{|c|c|c|c|c|c|c|c|}
\hline & \multirow{2}{*}{ 分 類 } & \multirow{2}{*}{ 種 名 } & \multicolumn{2}{|c|}{ 貴重種区分 } & \multicolumn{3}{|c|}{ 確認年度 } \\
\hline & & & 全国区分 & 都道府県区分（北海道） & 2000 & 2001 & 2002 \\
\hline \multirow[t]{2}{*}{ 植 } & 物 & ミクリ & 準緇隇他惧 & 希少種 & & 0 & 0 \\
\hline & & タマミクリ & 絶滅危惧口類 & & & 0 & 0 \\
\hline \multirow[t]{4}{*}{ 鳥 } & 類 & ヒシクイ & 緍润它惧 II 類 & 希少種 & & & 0 \\
\hline & & トモエガモ & 緦滅危惧 II 類 & 希少種 & & 0 & \\
\hline & & ミコアイサ & & 危急種 & & & O \\
\hline & & タンチョウ & 絶滅危惧 II 類 & 危总種 & 0 & 0 & 0 \\
\hline & 類 & エゾホトケドジョウ & 絶滅危惧 口類 & 份急種 & 0 & 0 & 0 \\
\hline \multirow{3}{*}{\multicolumn{2}{|c|}{ 底生:動物 }} & ミズスマシ & & 希少種 & & 0 & $\bigcirc$ \\
\hline & & キタヒメゲンゴロウ & & 希少種 & & & 0 \\
\hline & & オオコオイムシ & & 希少種 & 0 & 0 & 0 \\
\hline \multirow{2}{*}{\multicolumn{2}{|c|}{ トンボ類 }} & セスジイトトンボ & & 希少種 & 0 & 0 & \\
\hline & & ヒメリスアカネ & & 希少種 & & $\bigcirc$ & 0 \\
\hline
\end{tabular}

1999 年, 施「。池结河川串業所（2003）上り情。

\section{自然環境復元の問題点，課題および利点}

自然環境復元の技術を止しく失行するなら，野生生物の生息 地の維持確保や再生に大きな効果を得ると期待できる。自然環 境復元の技術は, 確実に成果を挙げつつあるが, 利点とともに 多くの問題点や課題を残しているので，以下にその点について 述べる。

\section{(1) 問題点と課題}

自然環境復元の技術の誤った導入は，新たな自然開拓を促し てしまう懸念がある。自然環境を復元する目的は，荒廃が進ん だ土地を自然に戻し，都市空間にはビオトープや咊いの場を提 供するところにある $[27,28,37,46]$ 。それゆえ，新たな自然 開拓の緩和措置としての導人は，極力避けたい。また，自然環 境復元は地域の個別性に依存する場合が多いので, 学識経験者, 行政関係者抢よび施工業者の間の深い連携のために互いの密接 な交流の場が必要となる。さらに, 地域住民の理解も必要であ る。近代文明化が進んだ現在では，さらなる自然開拓を進めつ つ利便性や即効性を求める傾向が顕著である。したがって，地 域住民の理解を得るために，「野生生物の重要さは伴侶動物や 産業動物と同等ないしそれ以上でもあり，どのようにして人間 の生存と関わっているのか」という具体的な教育の充実化が必 要である $[1,37]$ 。自然環境の復元には面積の確保や適切な場 の選択が必要なので，このためにも地域住民の理解が必要とな る。関連して，面積の確保をする上でゴミの大量化が大きな障 害であり，この解決なしに埋立て事業や不法投棄による生態系 の悪化は防げない。しかし, 本来, 資源として価值が無いゴミ の存在は有り得なく、リサイクルの完全化を妨げる原因は，安 值で購入できる原料を用いる製品製造が経済的に有利な生産シ ステムにある。この点に関して，Al（1992）は，リサイクル業
者や消費者に有利な経済政策の導大がリサイタルを円滑化して ゴミを大量に削減できるとしている $[51] 。$

学術的には，今のところ自然環境復元の施工地内で野生生物 を主軸にした追跡調査が十分になされている事例は稀である。 それゆえ，野生生物の追跡調査が十分になされていない場合， 地域住民や観察者の目撃情報に頼らざるを得ない面がある。植 物, 鼠虫, 魚類, 鳥類および小動物の再定着と個体数の回復は 定性的に確認されているが, 専門家による追跡調査を充実させ, 学術的な説得力をさらに強めていく必要がある。な拉，茂漁川 の追跡調查は 1997 年に終了しているが，この後著者によるサ ケの自然再生産の目視確認や地域住民によるオショロコマの目 撃情報がある。

(2) 利点

仮に，先の問題点と課題を克服できるなら，自然環境復元の 技術の推進は，新たな自然開拓を行うことなく経済効果を生む 真の循環型社会の形成へと繋がる。不要な建築物を取り壊して 面積を確保し, 緑地化を推進しながら従来の河川工法の施工地 を多自然型へと変え，野生生物が生息可能な土地を再生拡大さ せながら，人間の居住空間を集約都市へと移行させていく。そ のためには，人手が必要であるので, 雇用不足問題さえも䋸和 させる可能性を秘めている。

\section{自然環境復元の推進一全体計画案として一}

1 つの提案として, 自然環境復元の全体的な計画案を提示す る。自然環境復元の技術は，人の手によって自然の回復能力を 促す技術であるので，自然度が低い上地へ施工しても効果は低 いと思われる。逆に，白然度が高い上地の縁辺から施工してい くと大きな効果を得ると期待でき，そこから生息地を拡大させ る計画が得策である。 


\section{野生生物の保護に携る地球温暖化防止対策}

\section{（1）地域生態系の再生}

陸の自然度の指標として，世界には「地域別森林面積」，日 本には「植生自然度」がある $[40,52]$ 。基本的に野生生物は 植生の自然度に依存して分布しているので $[53,54]$, まずこ れらを指標にして，自然度が高い地域の縁辺から野生生物が生 息叮能な地域生態系を再生拡大させる計画を推奨する。また， 自然環境復元の技術は，地域の個別性に依存する場合が多いの で, 各都道府県の学識経験者, 行政, 施工業者扝よび地域住民 の間の深い連携のもと，植生自然度を指標とした自然林の再生 が望ましい。つまり，順応的管理を円滑に機能させて野生生物 が生息可能な自然林を再生させたい。幸運にも，日本の植生自 然度は都道府県毎の詳細が明らかにされており，自然度が高い 土地は全国に残っているので [40]，有効に活用したい。

（2）全体的な統合へ

広い移動性を持つ野生生物の生息地を確保するには，局所的 な地域の生態系の復元だけでは不十分である。したがって, 地 域生態系の再生拡大を進好とともに, 野生生物の移動に必要 な遷移帯（あるいはコリドー）としての自然林の再生拡大が必 要である [55-57]。遷移帯としての再生自然林は, 植生自然 度が高い土地どうしを繋げるように配置すると, 大きな効果を 得るであろう。

（3）森林から河川, 海洋沿岸域までの水脈に準じた生態系の 再生

野生生物の生息が可能な土地をさらなる広域空間としてとら えると, 再生自然林の拡大や天然林の保存にくわえて, 水脈に 準じた河川, 湖沼, 湿地, 農地あるいは海洋沿岸域までの水辺 空間の生息地の維持確保や再生が必要である。基本的には, 絶 滅が危惧されている野生生物は, 自然度が高い土地の水質が良 好な水脈に依存して分布しているので $[54,58]$, 天然林に水 源を持ち水質が良好である水脈に準じて多自然型河川工法を導 人し, そこから湖沼, 湿地, 農地あるいは再生自然林を再配置 させつつ, 野生生物が生息可能な土地を再生拡大させていく計 画を推奨する。

（4）都市空間では防災効果と㕷いの場を強調したビオトープ として

人口過密な都市空間においては，集約都市へ移行を進めつつ $[49,50]$, 自然環境復元の技術を導入していく計画が望ましい。 それゆえ, 多自然型河川工法は河床を拡大させて洪水災害に対 する防災面を強調し，再生自然林は防風林として機能するよう に配置し, な扔かつ, 都市空間のビオトープあるいは親水空間 となる想いの場として機能させる導入計画を推奨する。

（5）純工学的な手法は特効薬として

自然環境復元の技術の推進は, 生物多様性に豊富な自然生 態系を再生しながら大気中 $\mathrm{CO}_{2}$ を吸収固定する方向へと導く,
生態的な工法であるといえる $[27,28,34]$ 。自然林再生法は, 陸を緑化して大気中 $\mathrm{CO}_{2}$ を吸収固定しつつ, 野生生物へ生息 地を与える。多自然型河川工法は, 野生生物へ生息地を与えつ つ, 河川護岸の風化作用や運搬作用を通じ, 森林あるいは護岸 林の土塨中で生産される鉄, 銅およびケイ素などの海洋の一次 生産を高める元素を含む腐食物質や干潟を形成する砂碟を海洋 沿岸域へ供給する [30-34]。近年になり, 特に森林を背後に 持つ河川はその働きが大きいことが明らかにされてきており， 自然林再生法と多自然型河川工法を適切に組み合わせると, 大 きな効果を得ると期待できる。湖沼や湿地などの自然環境復元 は，一時的には大気中へメタンを放出しうるが [5]，野生生 物へ生息地を与えつつ, 施工地内における腐食物質の生成を促 して, 多自然型河川工法と同様に，水脈を通じて海洋沿岸域の 一次生産を促す元素や干潟を形成する砂礫を供給し [59], 大 気中 $\mathrm{CO}_{2}$ を吸収固定する方向へ導くと考えられる [30-34]。 なお，IPCCでは，天然の湖沼や湿地が温暖化へ及ぼす影響は メタンの放出量と有機物の生成による大気中 $\mathrm{CO}_{2}$ の吸収固定 量の釣り合いによって決まり，未だにこの詳細は明らかにされ ていないが，陸の炭素の貯蔵庫として極めて大きな役割を担っ ているとしている [5]。元来, 農地は $\mathrm{CO}_{2}$ の放出源であるこ とは変わりないが, 合鴨農法のように農薬を使用しない農法の 普及は，野生生物が生息可能な土地を再生拡大させつつ，希少 生物の野生復帰に適した健全な生息環境を形成していくと考え られる [45]。Toshihikoら (2001) は, 大都市近郊であっても, 房総半島北部の谷津と呼ばれる伝統的な農法地帯には絶滅危惧 生物種が豊富に生息していると述べており，これは農地の自然 環境復元が野生生物の生息地として機能することを示す具体事 例であるといえる [54]。

生態的な工法に対し, 海洋への $\mathrm{CO}_{2}$ の直接投棄は, 純工学 的な手法であるといえる [25]。純工学的な手法は, 特効薬的 な効果は期待できるが，海洋生態系に及ぼす悪影響が懸念され ているので [26], 今後は生態的な工法を推進して生物多様性 に豊富な自然生態系を再生させながら大気中 $\mathrm{CO}_{2}$ の吸収固定 を促進し，炭素の放出量を削減していき，万一危機的な状況へ と至ってしまった場合 $[20,21]$, 純工学的な手法をやむなく 適用したい。

\section{野生生物種の減少と絶滅}

\section{地球史における生物の大量絶滅}

生物の大量絶滅は, 過去 5 億年前から数えて 5 回起こった [60]。これらの大量絶滅の共通項を挙げると, 地球規模の気 候変動が生物の大量絶滅をもたらした（表 5)。これらの気候 変動に伴う地表気温変化は，お打むね $1 \sim 5{ }^{\circ} \mathrm{C}$ 範囲であっ た $[61,62]$ 。なかでも最も広く知られている事例としては， 
表 5 化石の記録による過去の生物の大量絶滅。David（1995）を加筆修正した。

\begin{tabular}{|c|c|c|c|c|}
\hline 紀 & 年代 (10 年) 1$)$ & 地球規模の気候変動 2 & 科の絶滅（\%) & 種の絶滅 (\%) \\
\hline オルドビス紀終末 & 439 & 寒冷化の進行 & $26 \pm 1.9$ & $84 \pm 7$ \\
\hline デボン紀末期 & 367 & 寒冷化の進行 & $22 \pm 1.7$ & $79 \pm 9$ \\
\hline 二畳紀終末 & 245 & 温暖化の進行 & $51 \pm 2.3$ & $95 \pm 2$ \\
\hline 三畳紀終末 & 208 & 温暖化の持続 & $22 \pm 2.2$ & $79 \pm 9$ \\
\hline 白亜紀終末 & 65 & 寒冷化の進行 & $16 \pm 1.5$ & $70 \pm 13$ \\
\hline
\end{tabular}

1) 年代は，現在よりさかのぼり，10 年単位で示した。

2) 気候変動に伴う地表気温変化は, 扔抢むね 1 から $5^{\circ} \mathrm{C}$ であった。

6,500 万年前の恐竜の大量絶滅が挙げられる。恐竜の大量絶滅 の原因は，ユカタン半島へ巨大な隕石が衝突した事件が引き金 となったという仮説が最も有力である $[63,64]$ 。しかし，確 かに 6,500万年前に形成された泥炭層などにおいて, 大規模 森林火災の痕跡である黒炭の存在や地表面には稀な元素である イリジウムが高濃度で存在することは確認されているが, 絶滅 自体は抢よそ数 10 数 100 万年にわたり進行したとされる $[60,65]$ 。

\section{現在における生物の大量絶滅}

種の体系的な命名と記録は, 17 世紀後半の比較的最近にな って始められた。現在では，およそ 150 万種の生物が記載さ れている [66]。しかしながら，すでに記載されている種とは 別に, 現存する種の本当の総数については極めて大きな不確 かさがあり，500万〜 1,500万種以上という推定もある $[67$, 68。いずれにせよ（多細胞）生物多様性が爆発的に増加した カンブリア紀以来, 地球上の生命の歴史は, 様々な変動や大 量絶滅による中断を繰り返しながら，基本的には拡大を続けて

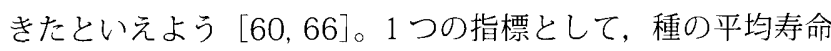
をみたい。化石の記録から, 種の起源から絶滅までの平均寿命 は, 100 万〜 1,000万年であった [65]。しかし，現在では， 約 14,000 種の鳥類と哺乳類の中から最低でも毎年 1 種が絶滅 しているので, 種の平均寿命はおよそ 1 万年になる。これは, 先の化石生物種の平均寿命より 100 倍〜 1,000 倍も短い。な おかつ, 現在進行している生物の大量絶滅の原因は, 人間活動 の活発化にあることは明白である $[6,65]$ 。さらに，生息地の 悪化や減少が原因となり, 希少生物種の絶滅の危険性は増加し, かろうじて絶滅を免れている生物種の野生復帰は難しいという 指摘がなされている $[45,69,70]$ 。

\section{期待される成果}

ここでは, 先に紹介した自然環境復元の技術を, 野生生物種 の減少や絶滅, 地球温暖化を緩和し, なおかつ双方の問題を早 期解決へ導く手段とみなし, 実行していく際に期待される成果 と遂行に伴う他の利点について考察する。

\section{おおまかな見積もり}

（1）どの程度の野生生物種が減少するか?

生息地の面積の減少に対する野生生物種の減少の割合は, Robert （1995）によると以下の式で近似できる [65]。

$$
\mathrm{S}=\mathrm{cA}^{\mathrm{Z}}
$$

ここで, $\mathrm{S}$ は種の数, $\mathrm{A}$ は生息地の面積を表し, $\mathrm{z}$ は通常 0.2 〜0.3をとる。定数cについては, 通常は各生息地の面積にお ける種の豊富さによって定めるが, ここでは現在の種の総数を 基準にして今後の種の減少の割合を求めるので, 現在を 1 と おいて計算する。また, $\mathrm{z}$ は近年の報告に基づいて 0.25 をと る [71］。2001 年世界森林白書によると, 世界の森林面積は, 1990 年には3,963,000 千 ha, 2000 年には 3,869,000干 ha であり, 1990年代には年間平均で9,400千haが減少した $[52] 。$ そのうち 2,900 千 ha は非熱帯林の森林面積の回復によるもの だが, 12,300 千 ha という熱帯林減少の影響がはるかに大き く効いている。この速度で熱带林面積が減少すると, 2100 年 までにその $68 \%$ にあたる 1,230,000千haが失われる。この 面積から計算すると, 熱帯林面積は世界の森林面積の 47\%で あるから [52], 1990 年代に存在した野生生物種の $2 \%$ はこ の期間にすでに失われ，さらに，そのうち $25 \%$ ぞ世紀内に 失われることになる。これは, 地球史において最悪なほど速い 速度となる。

（2）どの程度の野生生物種が守られ，これにどのような意味 があるのか?

生息地面積の維持確保によって守られる野生生物種の割合は 先の式を逆算して求めることができるが, 現存する生息地面積 の保存は, 野生生物種の個体群の維持のために極めて重要な役 割を担う。David ら（1994）は, たとえ生態的に優位であり絶 滅の危機に瀕していないと思われる野生生物種であっても，生 息地の破壊による潜行的な悪影響が予測できないほど急激な種 の絶滅を招く色険性について，近年はこの実現性が特に高いと 指摘している [6]。したがって, 現存する生息地面積の保存 と極めて自然に近い生態系の復元は, 潜行的な悪影響が招く野 生生物種の急激な絶滅をくい止めると期待できる。これに関連 して, Norman ら（2000）は, 野生生物種の豊富さが極めて高 
い土地を「生物多様性ホットスポット」として世界へ25 箇所 定義した [72]。生物多様性ホットスポットの殆どは天然林で ある。1990 年代に減少した熱带林のうち 1 年あたり $0.5 \%$ 以 上の純減少が確認された土地の大半は，この生物多様性ホット スポットに相当する $[52,72]$ 。過去の生物大量絶滅の後の生 物多様性回復期には，熱帯域や非熱帯域の大陸，あるいは孤島 に存在していた天然林が陸の動植物の適応放散を起こす原動力 として機能していたとされる $[73,74]$ 。それゆえ, 現存する 天然林の新たな開拓は, 将来の生物多様性の回復力を失いかね ない。さらに，表 2 に示した 1980 年代の陸の年間平均炭素 吸収量 $0.2 \mathrm{Gt} \mathrm{C}$ は, 土地利用の変化（主に森林伐採）による大 気への年間平均炭素放出量 $1.7 \mathrm{Gt} \mathrm{C}$ と相殺された值であり，実 際には，1.9Gt Cの吸収に相当する [5]。つまり，現存する天 然林の保存は, 将来の生物多様性の回復力を維持し, なおかつ 地球温暖化をくい止める原動力として極めて重要な役割を担う [73-75]。

（3）どの程度の量の炭素を吸収できるか？

最初に, 再植林によって吸収できる炭素量を見積もる。一 般的には, 土㙵の劣化が進んでいない熱带域に再植林を行う場 合，お括むね 50 年以内に元の森林としての機能回復が見込め る。1990 年から 2000 年までの期間に熱帯域で伐採された森 林の面積 123,000 千 haは, 上記の条件を十分に満たしている。 熱帯林の植生の炭素密度は, $99 \sim 174 \mathrm{t} \mathrm{C} / \mathrm{ha}$, 中央值は $131 \mathrm{t}$ C/ha である [76]。したがって, 123,000 千 haの熱帯林が自 然林再生法によって復元した場合の炭素吸収量は,

$$
123,000,000 \times 131=16 \mathrm{Gt} \mathrm{C}
$$

となり，2050 年までに打抽む 16Gt C の炭素が吸収できる。 この值を今後 50 年間に割り当てると, 1990 年代に大気へ残 った年間平均炭素量である $3.2 \mathrm{Gt}$ のちょうど $10 \%$ にあたる。 しかしながら，この值は，植生の炭素密度のみを考慮している ので, 上䁃への炭素の吸収固定と海洋の一次生産の増加を考慮 するならば，炭素吸収量はもう少々高まると期待できる。

次に，新規植林と再植林によって吸収できる炭素量を見積 もる。新規植林は, 一般的には,「過去 50 年以内に森林でな かった土地に対して積極的に植林すること」とされているの で，土壌の少化が進んでいる土地に植林することになる。そ れゆえ，水脈確保や土堙の改善を行うためにエネルギ一を必要 とし，その算定方法が異なるので，植林可能な面積は 67,000 千から 2,000,000 千 ha と非常に大きな幅を持つ [29]。IPCC は, 一例として, haあたりの累積炭素で今後 50 年間に約 $125 \mathrm{t} C, 100$ 年間に約 $210 \mathrm{t} \mathrm{C}$ を森林管理によって賄えるとし ている $[4]$ 。これらの值に基づいて累積炭素吸収量を見積も ると，2050 年までには 8〜 250Gt C, 2100 年までには 14 〜 420Gt Cを賄えることになる。しかし, これらの值は, 約
40 年毎に植林と森林伐採を繰り返しながら木材を有効な資源 として活用するためのシナリオであるので，生物多様性の維持 を考慮した森林管理を目的とするなら, 累積炭素吸収量の見積 もり值は, 全体的にやや低くなると考えられる。これらの大き な幅を持った見積もり値のどの值が実現可能となるかについて は，今後のエネルギー投資のありかたによって左右されるが, Schnitzler ら（1998）は, フランス北東部の鹿やイノシシが 生息するブナとナラの広葉樹林においては, 1 2 ha 以上の全 伐採を避ける森林管理が生物多様性の維持に適すると結論して おり [53]，このような研究の充実化が野生生物種の重要さへ の認識を深めつつ, 見積もり値の幅を小さくしていくであろう。

\section{自然環境復元に伴う他の利点}

日本における森林の面積は, 国土面積 3,778 万 ha のうち 2,515 万 haを占め，执よそ $66 \%$ である。そのうち，約 $40 \%$ は戦後の懸命な緑化活動の成果によるもので, 世界で有数の森 林国を造りあげた。しかしながら，この人工林の大半は杉と檜 が碁盤の目状に整列しているので, 野生生物種の多様性に乏し く, 台風洪水災害などに弱い。これの弊害についての具体的 な研究事例として, 杉檜の人工林と適切に間伐した人工林の間 の生物多様性は後者が有意に高かった [77]，1991 年 9 月 27 日に九州を襲った台風 19 号で被災した杉檜の人工林の植生構 造は物理的な応力に弱かった [78]，という報告が挙げられる。 さらには, 杉檜の人工林は, 花粉症などのアレルギーの増加を 促してしまった。ところが，これらの人工林は建築木材などに 使用するには成熟段階へと至っており，有効な資源として用い ることができる。今後, 人工林の伐採跡地や被災跡地へ自然林 再生法の施工を推進するならば，先に記した弊害を軽減できる であろう。また, 自然林再生法はその地域に固有な樹種を植え ることが大きな特徴であるので, 熱帯林などほぼすべての植生 帯に対して適用が可能である。さらには, 本来の植生分布より もやや広い緯度幅にわたって施工を推進させるなら, 地球温暖 化の進行に伴う気候変動に対して強い植生带を形成するととも に, 野生生物種に分散, 定着あるいは適応放散の場を与えると 期待できる。

一方，多自然型河川工法は，その源を辿ると，スイスにおい て頻発した莫大な洪水災害を軽減するために治水対策として開 発された工法である [44]。1871 年, スイス連邦議会は, 河 川流域の改修などの治水事業に対して積極的な経済援助を行う ことを決定し，1877 年には河川および湖沼に関する連邦法を 公布した。その結果, 頻繁に洪水が起こった広大な土地におい て，洪水災害は激減した。この事例は，日本においても当ては まるだろう。日本は, 地震や火山噴火, 台風などに伴う洪水泥 流災害の多発地帯であるので, 多自然型河川工法と自然林再生 法を組み合わせて遂行することによって，これらの自然災害の 
緩和に対する期待も大きい。

\section{負のフィードバック効果の加速を目指して}

今後, 人間活動の活発化による大規模な自然破壊に伴い, 最 も恐れられるシナリオは, 野生生物種の減少や気候変動が加速 度的に進行すること, すなわち, 正のフィードバック効果であ る $[6,20,21]$ 。これに対し, 負のフィードバック効果をもた らす生態系の再生が推奨される。自然環境復元の技術を推進さ せていくならば，負のフィードバック効果は加速する。多自然 型河川工法は, 河川水を通じて, 海洋の一次生産を高める微量 元素やケイ素を海洋沿岸域へ供給する。すると, 海洋沿岸域の 一次生産は活発化し, 大気中 $\mathrm{CO}_{2}$ 濃度を下げる(ケイ素を使 って外郭を造るケイ藻類は, この働きが特に強い)。大陸棚ポ ンプは, 海洋沿岸域で生産された有機物や溶存無機炭素を外洋 へと供給する $[79,80]$ 。それらは魚類や海棲哺乳類の糧を増 やし，さらには，サケマスなどの遡上をする魚類は有機物や栄 養塩を外洋から陸域生態系へともどす。陸域生態系が自然林再 生法によって天然に近い状態にあるなら, そこへ供給された有 機物は, 昆虫や鳥類の働きによって植物の成長を促進し, 大気 中 $\mathrm{CO}_{2}$ 濃度を下げつつ森林を形成拡大していく。そこには多 種多様な生物相が回復し, 自ずと大型野生動物が生息可能な土 地となる。

\section{今後へむけて}

IGYを契機に, ハワイのマウナロアにおいて, 大気中 $\mathrm{CO}_{2}$ 濃 度の連続測定を弟子のキーリング博士へ命じた人物は，米スク リップス海洋研究所の故レベル博士である。レベル博士は, 著 書のなかで, 地球温暖化への警告として「人類は, 地球を舞台に, たった一度きりの大実験を行おうとしている」と記した。つま り，二度目のチャンスはないということである。連続測定を開 始したキーリング博士でさえ, 連続測定開始当初は,「レベル 博士は，危機を大袈装にとらえているのではないか」と感じた という。一方, 生物多様性ホットスポットを定義したマイヤー ズ博士は，「生物圈を永い将来にわたり不毛化させるか否かは, 今後数十年内の人類の行動に左右される」と指摘している。本 稿において述べる必要はないかもしれないが, 野生生物種の減 少や絶滅, 地球温暖化を進めてきた原因は，人間の豊かさへの 欲望にあることは明白であろう。では，これに勝るとも劣らな いものは何かというと, まさに, 人間の生存欲そのものではな いだろうか。人間も生物であるので, 約 250 万年前から本格 的に道具の使用を始める以前は野性的に生きていた。環境教育 や環境倫理は未だ発展普及段階であるので, 残念ながら, 現時 点では人間の倫理観のみで野生生物種の減少, 絶滅扔よび地球 温暖化をくい止めることは至難であろう。裏を返すと, 問題を 早期解決へと導く道は, 人間の生存欲を有効活用するところに
あると考えられる。人類が今から約 1 万年前に本格的な農耕 牧畜を開始し，16 世紀に産業革命を起こしてから現在へ至る まで，自然の開拓が経済へと繋がる社会を形成してきた。そこ で見落とされてきたことは，自然破壊に対する経済的な無価值 であった [81]。大規模自然破壊をくい止め，復元させていく 技術はすでに様々存在しているので，これらの実行が至難なの ではないだろうか。これらの実行が個人の生活基盤や組織の利 益を生む社会システムの構築が最良ではないだろうか。これよ り未来は, 自然生態系の維持回復が経済へと繋がる社会の構築 が必要である。つまり, 環境污染をくい止め浄化させることや, 自然環境を維持確保し復元することが経済へと繋がる社会シス テムの構築が望ましい。

\section{要 約}

野生生物の減少や絶滅が急激に進行している現在, 野生生物 の保護管理は，ますます重要な課題となりつつある。絶滅が危 惧されている野生生物の減少の原因は，主にこれらの生息地の 悪化や減少であるとされている。そのため, 生息地の維持確保 は, 野生生物の減少や絶滅をくい止める上で大きな効果が得ら れると期待できる。さらに, 野生生物が生息可能な自然環境を 復元させていくならば，より大きな効果を得るだろう。一方， 地球温暖化問題は，陸域生態系と深い繋がりがある。1990年 代には，人間活動により，炭素換算で年間平均 $6.3 \mathrm{Gt} \mathrm{C}$ の二酸 化炭素が大気中へ放出された。そのうち 3.2Gt C が大気へ残り, $1.7 \mathrm{Gt} \mathrm{C}$ が海洋へ吸収され, 残りの $1.4 \mathrm{Gt} \mathrm{C}$ は陸域生態系へ吸 収された。このように, 陸域生態系は炭素の吸収源として大き な役割を担っているので，この吸収能力は「気候変動に関する 政府間パネル」において地球温暖化防止対策として有効視され ている。このような陸域生態系を野生生物が生息可能な土地と して復元させるなら, 双方の問題を早期解決へと導くであろう。 キーワード：野生生物の保護, 生息地, 二酸化炭素, 地球温 暖化, 自然環境復元

\section{謝辞}

地球化学的輪廻の哲学を伝えて下さった北海道大学大学院 地球環境科学研究科の角皆静男名誉教授, 疫学の洞察力を与え て下さった酪農学園大学獣医学部公衆衛生学教室の森田千春教 授，本稿をまとめるにあたり，助言を賜った同大学同学部の浅 川満彦助教授 (野生動物学)，データ転載と提供を承諾して下 さった北海道庁と北海道開発局の皆様, 北海道大学農学部の東 三郎名誉教授, ならびに環境問題の解決や災害防止，野生生物 保護管理へ尽力されている皆様へ深く感謝いたします。 


\section{野生生物の保護に携る地球温暖化防止対策}

\section{引用文献}

1. 大泰问紀之，1996. 個体群調節の必要性とその方法一野生動物獣医学展 開の方向について一.JpnJ Zoo Wildl Med 1:2-7.

2. 岸本真二. 1997. 日本に打ける保護管理活動と獣医学.Jpn J Zoo Wildl Med 2: 3-8.

3. 安田直人，1997. 絶滅の抢それのある野生生物の保護について,JpnJ Zoo Wildl Med 2: 73-79.

4. IPCC Working Group III. 2001. Climate Change 2001: Mitigation. Cambridge Univ. Press, Cambridge.

5. IPCC Working Group I. 2001. Climate Change 2001: The Scientific Basis. Cambridge Univ. Press, Cambridge.

6. David T, Robert MM. Clarence LL, Martin AN. 1994. Habitat destruction and the extinction debt. Nature 371:65-66

7. Keeling CD. Bacastow RB, Bainbridge AE, Ekdahl CA, Guenther PR, Waterman LS. 1976. Atmospheric carbon dioxide variations at Mauna Loa Observatory, Hawaii. Tellus 6: 538-551.

8. Peterson JT, Komhyr WD, Waterman LS, Gammon RH, Thoning KW, Conway TJ. 1986. Atmospheric $\mathrm{CO}_{2}$ variations at Barrow, Alaska, 1973-1982. JAtmos Chem 4: 491-510.

9. Keeling CD, Adams JA, Ekdahl CA, Guenther PR. 1976. Atmospheric carbon dioxide variations at the South Pole. Tellus 6: 552-564.

10. Kane RP, Paula ER. 1996. Atmospheric $\mathrm{CO}_{2}$ change at Mauna Loa, Hawaii. J Atmos Terr Phys 58: 1673-1681.

11. Fumio W, Osamu U, Yasuhiro J, Masamichi A, Keishirou H, Yoshiaki H, Kazuhiro T, Kazuto S. 2000. Interannual variation of growth rate of atmospheric carbon dioxide concentration at the JMA's three monitoring stations: large increase in concentration of atmospheric carbon dioxide in 1998. J Meteorol Soc Jpn 78: 673-682.

12. Hisayuki Yl, Hidekazu M. 2001. Measurements of atmospheric $\mathrm{CO}_{2}$ from a meteorological tower in Tsukuba, Japan. Tellus 53B: 205-219.

13. IPCC Working Group I . 2001. Climate Change 2001: Impacts, Adaptation, and Vulnerability. Cambridge Univ. Press, Cambridge.

14. Ken W. 2000. Global warming and the spread of disease: the debate heat up. Trends Ecol Evol 15: 488.

15. Michael M. 2001. Uncertain impact of global warming on disease. Lancet 357: 1183 .

16. 甲斐知恵子：1997. 伝染病が野生動物個体群に及ぼす影響.Jpn J Zoo Wildl Med 2: 13-17.

17. Morihiro Y. Tsuyoshi Y, Yasukazu M, Chiharu M, Hiroshi U. 1997. Seroepidemiological study of Coxiella burnetii in Cervus Nippon in Northern Japan. Jpn J Zoo Wildl Med 2: 101-106.

18. Mitsuhiko A. Shigeru N, Mark AB. 2002. An overview of infectious and parasitic diseases in relation to the conservation biology of the Japanese Avifauna. J Yamashina Inst Ornithol 34: 200-221.

19. Louria BD. 2000. Emerging and re-emerging infections: the societal determinations. Futures 32: 581-594.

20. Gerald RD. 2003. A methane trigger for rapid warming ?. Science 299: 1017.

21. Glasby GP. 2003. Potential impact on climate of the exploitation of methane hydrate deposits offshore. Mar Pet Geol. 20: 163-175.
22. Yutaka WW, Tsuneo O, Akifumi S, Tomoya S, Masahide W, Syuichi W. 2001. Probability of a reduction in the formation rate of the subsurface water in the North Pacific during the 1980s and 1990s. Geophys Res Lett 28: 3289-3292

23. Bernhard S, Gregg M. 1998. The Kyoto protocol: provisions and unresolved issues relevant to land-use change and forestry. Environ Sci Policy 1: 313-327.

24. Christian A. Stephen HS. 2002. Are the economic costs of stabilising the atmosphere prohibitive?. Ecol Economics. 42: 73-80.

25. Katsumi T, Hiroaki M, Takayuki S. 1997. Absorption dynamics of $\mathrm{CO}_{2}$ bubbles in a pressurized liquid flowing downward and its simulation in seawater. Chem Eng Sci 52: 41 19-4126.

26. Yoshihisa S. 1998. Biodiversity and biological impact of ocean disposal of carbon dioxide. Waste Manage 17:381-384.

27. 岡村俊邦. 1998. 住㞎参加による自然林再生法一生態学的混播法の理論 と実践一. 財団法人石狩川振興財団, 札幌.

28. 東 三郎. 1999. 森づくりの技と心ー1975 年「罯境林をつくる」全文 復刻含む一。株式会社ギミック，札幌。

29. 小木知子. 1998. バイオマスエネルギー利用による $\mathrm{CO}_{2}$ 削減効果. NIRE 二ュース，資源環境技術総合研究所（現産業技術総合研究所），筑波，

30. Katsuhiko M, Jun N, Kenshi K, Kenji, T, Yoshihiro S. 1998. Riverine input of bioavailable iron supporting phytoplankton growth in Kesennuma Bay (Japan). Wat Res 32: 3436-3442.

31. Paul GF. Richard TB, Victor S. 1998. Biogeochemical controls and feedbacks on ocean primary production. Science 281: 200-206.

32. Öztürk M, Steinnes E, Sakshaug E. 2002. Iron speciation in the Trondheim fjord from the perspective of iron limitation for phytoplankton. Est Coast Shelf Sci 55: 197-212.

33. 宇野木早苗. 2002. 河川事業が治岸環境へ与える影響を物理面から考え る. 海の研究 11:637-650.

34. 谷田- - . 1999. 生態学的視点による河川の自然復元：生態的循環と連 続性について. Ecol Civil Eng 2: 37-45.

35. 杉山恵一. 1992. 自然環境復元の理念と理論. 自然環境復元の技術（杉 山恵一, 進士五十八編),pp. 1-8. 朝倉書店, 東京.

36. 鴜谷いづみ. 1998. 生態系管理における順応的管理. 保全生態学研究 3: 145-166.

37. 千歳川河川事務所. 2002. 漁川における魚道の設置について一計画から 工事施工までの経過報告一. 北海道開発局石狩川開発建設部干歳川河川 事務所, 千歳

38. 千歳川河川事務所. 2003. 石狩川改修工事の内漁川外魚類 - 鳥類調査棠 務報告書. 北海道開発局石狩川開発建設部干歳川河川事務所。千歳.

39. 国土交通省. 2003. 平成 14 年全国一級河川0水質現況（国土交通省河 川局編)，東京.

40. 環境庁自然保護局（現環境省自然保護局）１996. H本の植生一第 4 [品] 自然濖境保全基礎調查植生調查報告書（全国版）一(镮境庁自然保護同編）, 東京.

41. 馬場仁志. 2001. 多自然型川づくりの事例評価一現地ワータショップに よる評価の試み一. Ecol Civil Eng 4:49-58.

42. 豊島照雄, 中野 繁, 井上幹生, 小野有五, 倉茂好臣. 1996. コンクリ一 ト化された河川流路における生息場所の再造成に対する魚類個体群の反 応.JpnJEcol 46: 9-20. 
43. 小野有五. 2001. 十勝の森と川: ヌップク川・サッナイ川・第二柏林台 川の緑の回廊. 森と川 (北海道の森と川を語る会編), pp. 20-27. 江別. 44. ゲルディーC, 福留脩文. 1994. 近自然河川工法の研究一生命系の土木 建築技術を求めて一. 信山社, 東京.

45. 村田浩一. 1999. コウノトリ野生復帰のための諸課題一住民との協力関 係はか一.JpnJ Zoo Wildl Med 4: 17-25.

46. 池田河川事務所. 2003. 礼作別湿地ビオトープの生態系について. 北海 道開発局带広開発建設部池田河川事務所, 池田.

47. 宇野木早苗. 2001. 川と海の関係一物理的観点から一, 沿岸海洋研究 39: 69-81.

48. 人工干潟実態調查委員会. 1998. 野鳥の渡来数からみた人工干潟の評価. 人工干潟調查報告書（世界自然保護基金日本委員会，人工干潟実態調査 委員会編），pp. 59-65. 東京.

49. Etsuo Y, Ponnusamy J. 1997. Analysis on urban ecosystems changes monitoring using geographical information systems. In Ultra-long-term Cryogenic Preservation Network of Biological and Environmental Specimens (Toshikazu S, Takeharu T. ed. ), pp. 156-163

50. Etsuo Y. 1996. Model reference adaptive system for global environmental planning. In Model Reference Adaptive Global Environmental Planning (Etsuo Y, Thirumurthy AM ed.), pp. 1-41. Institute of Environmental Creation, International, Sapporo.

51. Al G. 1992. The wasteland. In Earth in the Balance: Ecology and the Human Spirit (Al G), pp. 145-163. Houghton Mifflin, New York.

52. Food and agriculture organization of the United Nations. 2001. State of the world's forest, Rome (http: //www. fao. org/docrep/003/y0900e/ y0900e00. htm)

53. Schnitzler A, Borlea F. 1998. Lessons from natural forests as keys for sustainable management and improvement of naturalness in managed broadleaved forest. For Ecol Manage 109: 293-303.

54. Toshihiko N, Kevin S. 2001. Land-use planning and distribution of threatened wildlife in a city of Japan. Landscape Urban Plann 53: 1-15.

55. Douglas TB, Thomas AS, John TR. 2001. Use of corridor-like landscape structures by bird and small mammal species. Biol Conserv 102: 213-224.

56. Mario P, Alberto M, Elisa P. 2004. A habitat model for brown bear conservation and land use planning in the central Apennines. Biol Conserv 118: $141-150$

57. Thomas BS, Salit K, Christopher JS, Robert KW. 2001. Biodiversity hotspots and beyond: the need for preserving environmental transitions. Trends Ecol Evol 16: 431.

58. Wei J, Clinton J. 2000. Spatial modeling of the geographic distribution of wildlife populations: a case study in the lower Mississippi River region. Ecol Model 132: 95-104.

59. Delaune RD, Jugsujinda A, Peterson GW, Patrick WH. 2003. Impact of Mississippi River freshwater reintroduction on enhancing marsh accretionary process in a Louisiana estuary. Est Coast Shelf Sci 58: 653-662.

60. David J. 1995. Extinctions in the fossil record. In Extinction Rates (John HL, Robert MM ed. ), pp. 25-44. Oxford Univ. Press, Oxford.

61. 長尾 隆. 星野常雄. 1991. 地質資料に見る炭酸ガスの役割. 炭酸ガスと 地球環境の变遷 (長尾 隆, 星野常雄著), pp. 16-20. 地人書館, 東京.

62. Siegfried F, Konrad JK, Werner VB, Christine B. 2002. Long-term evolution of the global carbon cycle: historic minimum of global surface temperature at present. Tellus 54B: 325-343.

63. Richard AK. 2002. No 'darkness at noon' to do in the dinosaurs ?. Science 295: 1445-1447.

64. Zi KZ, Xue YM, Zhi FC, Gao CY, Ping K, Mitsuru E, Zhen HZ. 2002. A possible causal relationship between extinction of dinosaurs and $\mathrm{K} / \mathrm{T}$ iridium enrichment in the Nanxiong Basin, South China: evidence from dinosaur eggshells. Palaeogeogr Palaeoclimatol Palaeoecol 178: 1-17.

65. Robert MM, John HL, Nigel ES. 1995. Assessing extinction rates. In Extinction Rates (John HL, Robert MM ed. ), pp. 1-24. Oxford Univ. Press, Oxford.

66. Robert MM. 1999. The dimensions of life on earth. In Nature and Human Society: The Quest for a Sustainable World (Peter HR ed. ), pp. 30-45. The National Academies Press, Washington DC.

67. Philip HM. 1995. The current magnitude of biodiversity. In Global Biodiversity Assessment (Heywood VH, Watson RT ed. ), pp. 113-138. Cambridge Univ. Press, Cambridge.

68. James LE, Meredith AL, Ebbe SN. 2000. Interoperability of biodiversity databases: biodiversity information on every desktop. Science 289: 2312-2314

69. 早矢仕有子. 1999. 絶滅危惧種保全に扔ける生息地保全の重要性 一シ マフクロウ（Ketupa blakistoni）を例にして一.Jpn J Zoo Wildl Med 4: 27-31.

70. 白木彩子. 1999. 北海道に扔けるオジロワシ Haliaeetus albicilla の生息 の現状とその保全.Jpn J Zoo Wildl Med 4: 33-37.

71. Robert MM, Michael PHS. 2000. Species-area relations in tropical forests. Science 290: 2084-2086.

72. Norman M, Russell AM, Cristina GM, Gustavo ABF, Jennifer K. 2000. Biodiversity hotspots for conservation priorities. Nature 403: 853-858.

73. Alan C, David P. 1997. Mass survival of birds across the CretaceousTertiary boundary: molecular evidence. Science 275: 1109-1113.

74. Price T, Gibbs HL, Desousa L, Richman AD. 1998. Different timing of the adaptive radiations of North American and Asian warblers. Proc $R$ Soc Lond B 265: 1969-1975.

75. Knohl A, Schulze ED, Kolle O, Buchmann N. 2003. Large carbon uptake by an unmanaged 250-year-old deciduous forest in Central Germany. Agric For Meteorol 118: 151-167.

76. Dixon RK, Brown S, Houghton RA, Salomon AM, Trexler MC, Wisniewski, J. 1994. Carbon pools and flux of global forest ecosystems. Science 263: 185-190.

77. Dinesh RB, Masahiro O. 2001. Patch implications in the maintenance of species richness in an isolated forest site. Biol Conserv 98: 117-125.

78. Yukihiro C. 2000. Modelling stem breakage caused by typhoons in plantation Cryptomeria japonica forests. For Ecol Manage 135: 123-131.

79. Shizuo T, Shuichi W, Tetsuro S. 1999. Is there a "continental shelf pump" for the absorption of atmospheric $\mathrm{CO}_{2}$ ?. Tellus 51B: 701-712.

80. Yool A, Fasham MJR. 2001. An examination of the "continental shelf pump" in an open ocean general circulation model. Global Biogeochem Cycles 15: 831-844.

81. イムラーH. 1993. 経済学は自然をどうとらえてきたか（栗山 純 訳）, 農文協. 東京. 